\title{
Funkcjonowanie obiektów w trwałej ruinie na przykładzie zamku w Janowcu
}

\author{
Katarzyna Drobek \\ https://orcid.org/0000-0003-3599-1169 \\ k.drobek@pollub.pl \\ Katedra Konserwacji Zabytków, Wydział Budownictwa i Architektury, Politechnika Lubelska
}

\begin{abstract}
Streszczenie: Ruiny zamkowe są stale obecne w krajobrazie Polski. Wzrost zainteresowania tego typu obiektami powoduje, że są one przystosowywane do funkcji współczesnych w celu zapewnienia im dalszego funkcjonowania. Zamek w Janowcu, na którym skupia się niniejszy artykuł, w czasach swojej świetności był rezydencją znamienitych rodów magnackich. Zamek ten jest niezwykle ciekawym przykładem zamków średniowiecznych funkcjonujących w formie trwałej ruiny, dlatego też na jego przykładzie zostanie omówione obecne działanie tego typu obiektów.
\end{abstract}

Słowa kluczowe: zamek, ruina, trwała ruina, Janowiec, muzeum

\section{Wstęp}

Zamki w ruinie na stałe wpisały się w krajobraz Polski. Odnotowywany jest ciągły wzrost zainteresowania obiektami tego typu. Średniowieczne zamki, niezależnie od pełnionej aktualnie funkcji są wyjątkową atrakcją turystyczną. Dodatkowo ich malownicze położenie przyciąga wielu turystów. W obecnych czasach wiele obiektów zabytkowych ulega przekształceniom, w celu dostosowania ich do współczesnych standardów. Prowadzi to do utraty ich autentyzmu oraz wartości zabytkowych. Działania te nie omijają również zamków w ruinie. W przypadku obiektów zachowanych w formie trwałej ruiny podejmowane są próby odtwarzania kubatur zamkowych bądź też wprowadzania nowych uzupełnień w tkankę zabytkową. Powodem tego jest zaspokajanie potrzeb użytkowych dla współczesnych funkcji, które potrzebują przestrzeni spełniającej obecne standardy. ${ }^{1}$

Najczęściej ruiny zamkowe przekształcane są na ogólnodostępne funkcje społeczno-kulturalne. Adaptowane są zwykle na cele muzealne bądź też wystawiennicze, stając się przy tym ważnym dla lokalnej społeczności i odwiedzających turystów publicznym otwartym obiektem. Budynki zabytkowe są także często przystosowywane do takich funkcji, ponieważ stanowią naturalne tło dla wystawianych dzieł, które bardzo często pochodzą z tego samego okresu co obiekt. Dodatkowo funkcja muzealna jest stosunkowo mało uciążliwa i przede wszystkim nie powoduje niszczenia cennej substancji historycznej, a to daje możliwość utrzymania zagrożonego obiektu architektonicznego.

Podobnie wygląda sytuacja na zamku w Janowcu. W czasach swojej świetności był rezydencją znamienitych rodów magnackich: Firlejów, Trałów i Lubomirskich. Obecnie obiekt utrzymywany jest w formie trwałej ruiny oraz przystosowany jest w części do pełnienia funkcji turystycznych. Jego budowa rozpoczęła się w 1496 roku. Firlejowie stawiali obiekt, który przystosowany był już do aktywnej obrony artyleryjskiej. Tym samym rozpoczął on bastejowy system obronny na terenach Lubelszczyźnie. Niestety, przez zmienne losy mające miejsce na przestrzeni wieków powoli zaczął popadać w ruinie. Obecnie zamek w Janowcu jest jednym z oddziałów Muzeum Nadwiślańskiego w Kazimierzu Dolnym. 


\section{Ruiny zamku w Janowcu}

Zamek w Janowcu jest obecnie jednym z sześciu oddziałów Muzeum Nadwiślańskiego w Kazimierzu Dolnym. Położony jest w Gminie Janowiec, na terenie Małopolskiego Przełomu Wisły, w zachodniej części trójkąta turystycznego Puławy-Kazimierz Dolny-Nałęczów. Dzięki takiemu usytuowaniu, ruiny zamku są niezwykle często odwiedzanym obiektem.

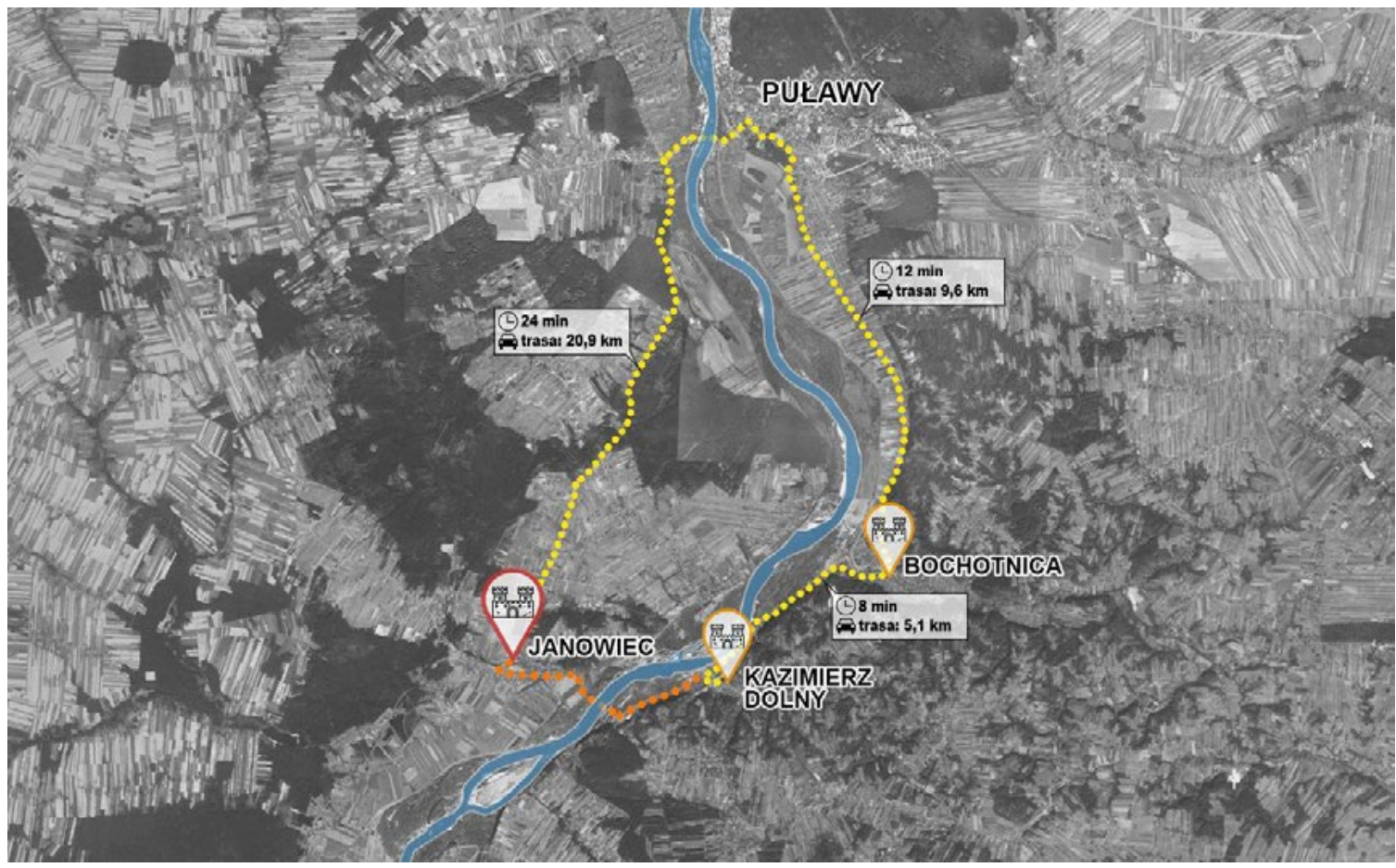

Ryc. 1. Lokalizacja Janowca względem najbliższych ośrodków, Źródło: opracowanie własne na podkładzie https://www. google.pl/maps

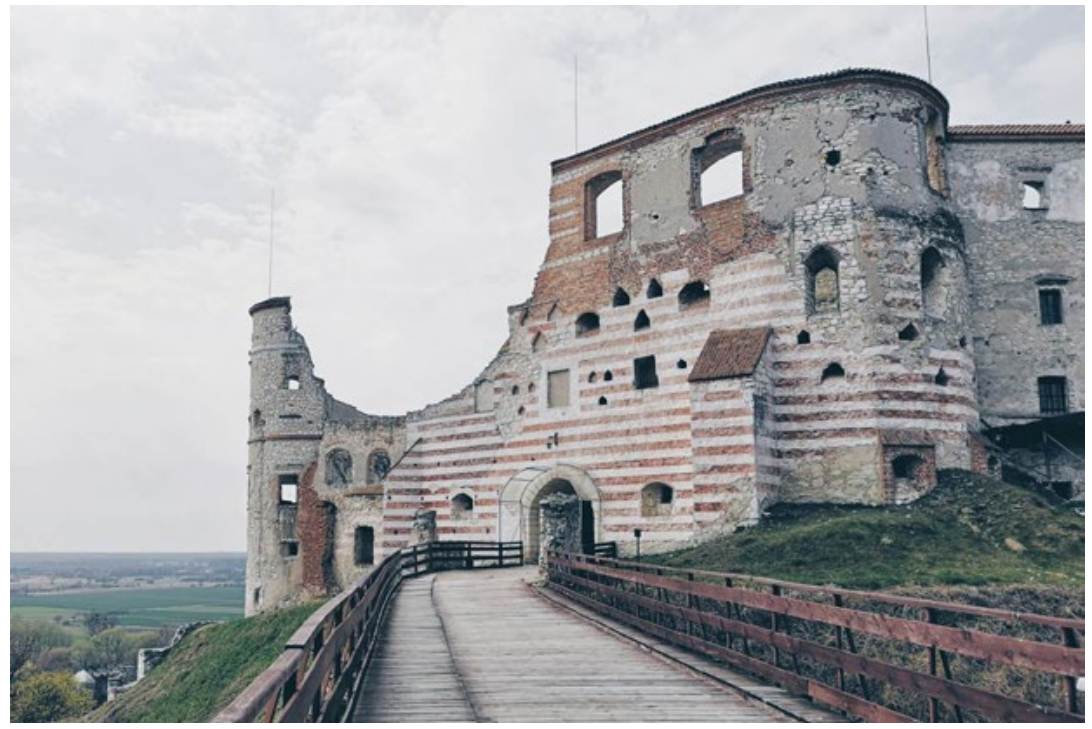

Ryc. 2. Widok na budynek bramny zamku w Janowcu. Autor: Katarzyna Drobek 
Ruiny renesansowego zamku usytuowane na lewym brzegu Wisły w największym przewężeniu jej przełomu, na skraju wyżynnego cypla oddzielonego od rozległego płaskowyżu naturalnym wąwozem. Od strony wschodniej znajduje się równina, od której wydzielono go fosą. Dzięki temu uzyskano idealne, obronne położenie zamku, które odcięte jest od trzech stron stromymi stokami, natomiast czwarta strona była doskonałym miejscem na lokalizację przedzamcza, zaplecza gospodarczego i ogrodu.

Warownia wchodzi w skład zespołu krajobrazowo-architektonicznego Janowca, który obejmuje zespół zamkowy wraz z parkiem i zespołem dworskim, zespół kościelny oraz historyczny układ urbanistyczny rynku i ulic. Zespół zamkowy wpisany jest do rejestru zabytków pod nr dec. A/500.

Budowa janowieckiego zamku przypada na przełom XV i XVI w. Jego inicjatorem i fundatorem był Mikołaj I Firlej. Obiekt ten w pełni przystosowany był do ukształtowania terenu. Miał kształt nieregularnego, wydłużonego wieloboku o wymiarach $125 \times 65 \mathrm{~m}$. Charakterystycznymi elementami dla pierwszej fazy budowy bastejowego zamku w Janowcu była baszta wschodnia, zwana również puntone oraz basteja przybramna znajdująca się w narożu północno-wschodnim. ${ }^{2}$ Dodatkowo w tym okresie powstała basteja wielka, dwie wieże mieszkalno-obronne i prawdopodobnie wieża w narożu południowo-zachodnim. Wszystkie elementy warowni połączone były ze sobą murami kurtynowymi z dwoma poziomami strzelnic, które otaczały ogromny dziedziniec. Układ zamku pochodzący z tego czasu obrazuje ryc. 3.
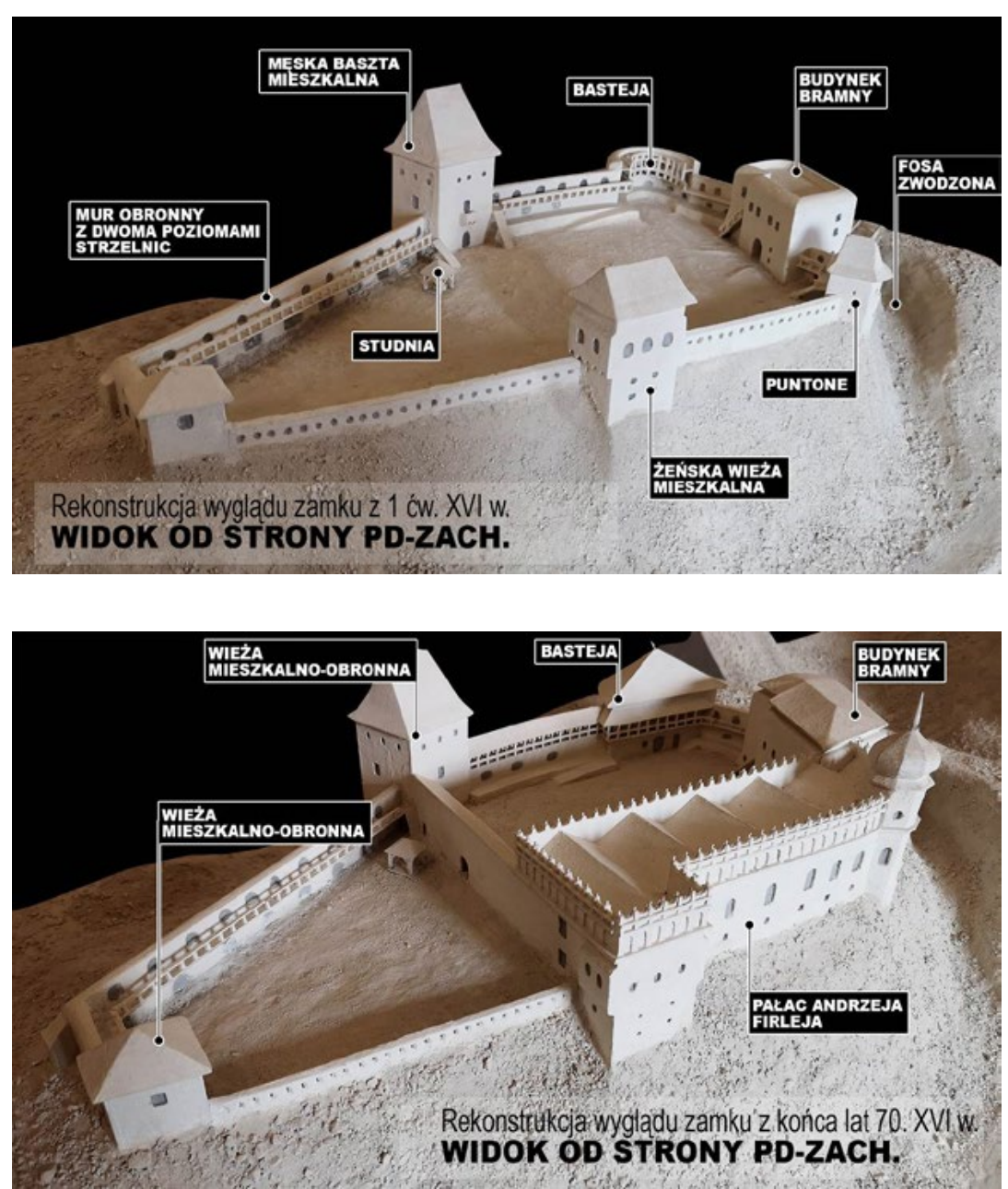

Ryc. 3. Rekonstrukcja wyglądu zamku z 1 ćw. XVI w. Źródło: opracowanie własne $z$ użyciem fotografii makiety znajdującej się w Muzeum na Zamku w Janowcu.

Ryc. 4. Rekonstrukcja wyglądu zamku z końca lat 70. XVI w. Źródło: opracowanie własne $z$ użyciem fotografii makiety znajdującej się w Muzeum na Zamku w Janowcu. 
Druga połowa XVI w. przyniosła przebudowę zamku. Zamek w Janowcu traci swoją dominującą funkcję obronną. W latach 1565-1579 Santi Gucci Fiorentino na prośbę Andrzeja Firleja dokonał rozbudowy warowni janowieckiej na rezydencję mieszkalną (Ryc. 3). Południowo-wschodnia część zamku zmieniła się w renesansowy pałac. Pojawiły się charakterystyczne elementy, takie jak attyka, krużganki oraz reprezentacyjne schody. Wielka przestrzeń dziedzińca, została podzielona ścianą z krużgankami kolumnowymi.

Ród Tarłów, będący kolejnym właścicielem zamku, w dalszym ciągu kontynuował rozbudowę warowni na rezydencję mieszkalną. Przebudowano pałac Andrzeja Firleja, natomiast amfilada południowa w swej zachodniej części powiększona została o pałac. Pojawiły się również dwie cylindryczne wieże, z czego jedna zajęła miejsce dawnego puntone. Do północnej części murów obronnych dobudowany został dom północny oraz skrzydło z czterema kondygnacjami krużganków.

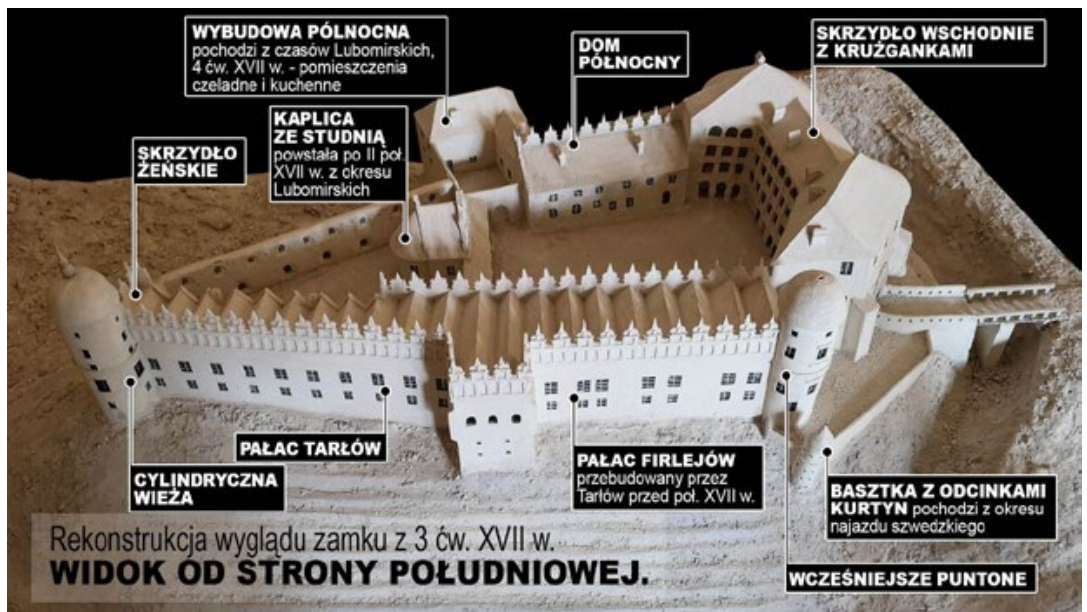

Ryc. 5. Rekonstrukcja wyglądu zamku z 3 ćw. XVII w. Źródło: opracowanie własne z użyciem fotografii makiety znajdującej się w Muzeum na Zamku w Janowcu.

Zamek w Janowcu uzyskał swój ostateczny kształt w II połowie XVII w. przez Lubomirskich. W miejscu wieży północnej powstała wybudowa czeladna. Nad studnią znajdującą się na Małym Dziedzińcu powstała Kaplica. Nieco rozbudowany został pałac Tarłów. Zmienione zostały również okna całej amfilady południowej i ozdobiono je obramieniami rokokowymi. ${ }^{3}$

Zamek zaczął popadać w ruinę, w 1931 r. właścicielem został Leon Kozłowski i był nim aż do 1975 r., kiedy to został wykupiony przez Muzeum Nadwiślańskie w Kazimierzu Dolnym. W imieniu Państwa kupiło ono z rąk prywatnych zamek wraz z otaczającym go terenem. ${ }^{4} \mathrm{~W}$ momencie przejęcia go, najbardziej zniszczoną jego częścią była amfilada południowa. Z pierwotnej formy zachowała się ściana południowa z dużymi ubytkami, ceglany ryzalit, a przy Dziedzińcu Małym także ściana północna i wewnętrzne ściany działowe, na których przetrwały relikty sztukaterii. Pod zagruzowaną częścią parteru wschodniego odcinka amfilady, znajdowały się relikty murów pałacu Andrzeja Firleja. Po krużgankach w Dziedzińcu Wielkim i ganku w Dziedzińcu Małym pozostały tylko fundamenty pod filary i schody.

3 Gruszecki A., Zamek w Janowcu w świetle badań, [w:] Ruiny żywe: adaptacja zabytków architektury do celów muzealnych: nowe inspiracje i funkcje dla Zamku w Janowcu: materiały z sympozjum naukowego z okazji 30-lecia Muzeum Zamek w Janowcu, Kazimierz Dolny - Janowiec, 2007 s. $14-16$,

4 Żurawski J., Okoliczności i cel nabycia zamku w Janowcu nad Wisłą. Przebieg jego konserwacji, restauracji i zagospodarowania, [w:] Ruiny żywe: adaptacja zabytków architektury do celów muzealnych: nowe inspiracje i funkcje dla Zamku w Janowcu: materiały z sympozjum naukowego z okazji 30-lecia Muzeum Zamek w Janowcu, Kazimierz Dolny - Janowiec, 2007 s. 17, 

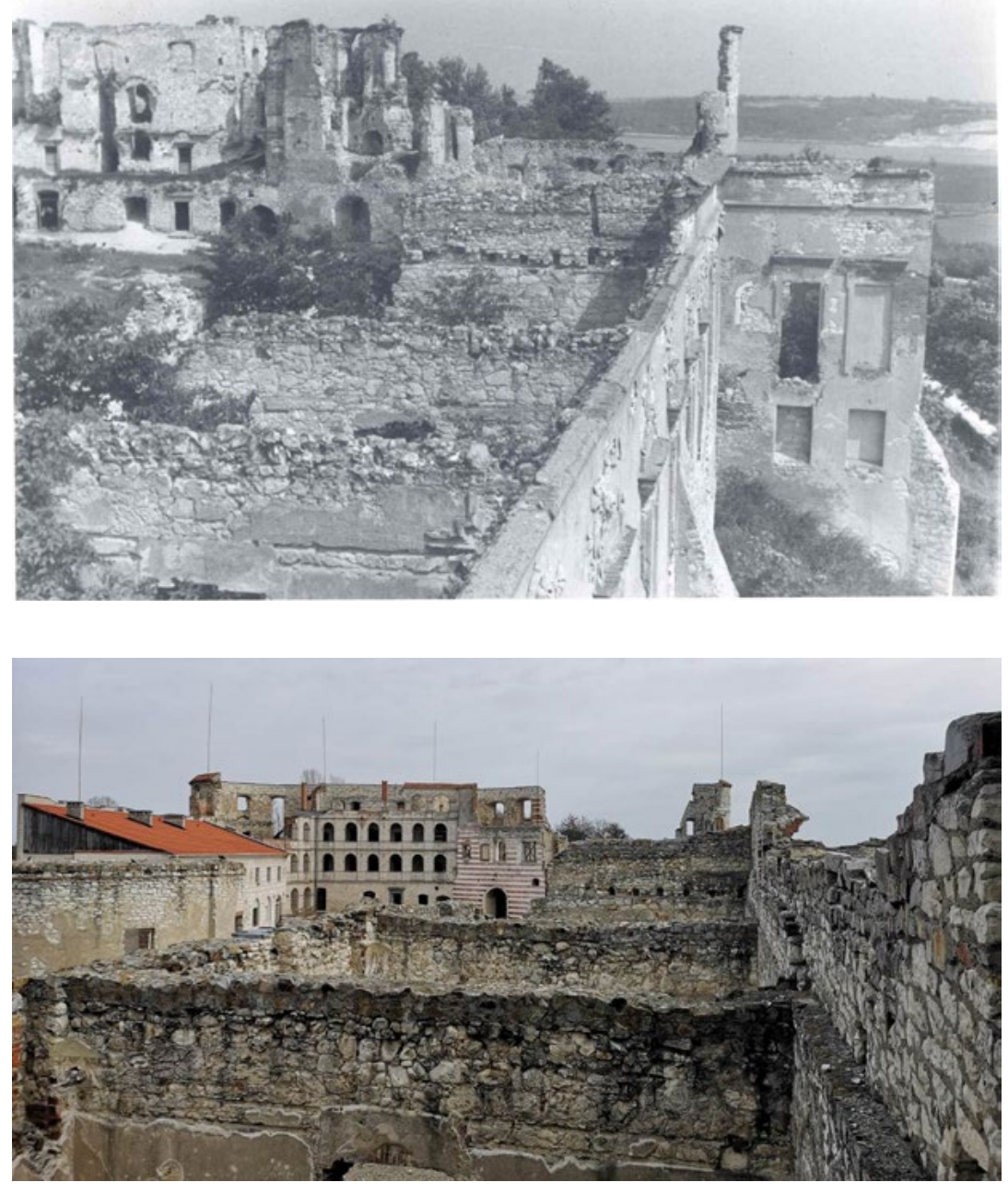

Ryc. 6. Zamek Janowiec-amfilada południowa oraz część budynku bramnego, b.a., 1952 r. Źródło: Fotografia ze zbiorów MNKD

Ryc. 7. Widok na amfiladę południową oraz budynek bramny i skrzydło wschodnie. Autor: Katarzyna Drobek

W tym czasie MNKD zleciło kompleksowe prace, w których skład wchodziła inwentaryzacja zamku, badania archeologiczne, historyczne, architektoniczno-historyczne, polichromii oraz projekt i realizację konserwacji ruin wraz z częściową odbudową zamku. Przeprowadzono również prace mające na celu uporządkowanie zieleni, a także utworzenie skansenu w sąsiedztwie ruin zamkowych oraz wykonanie ekspozycji muzealnych.

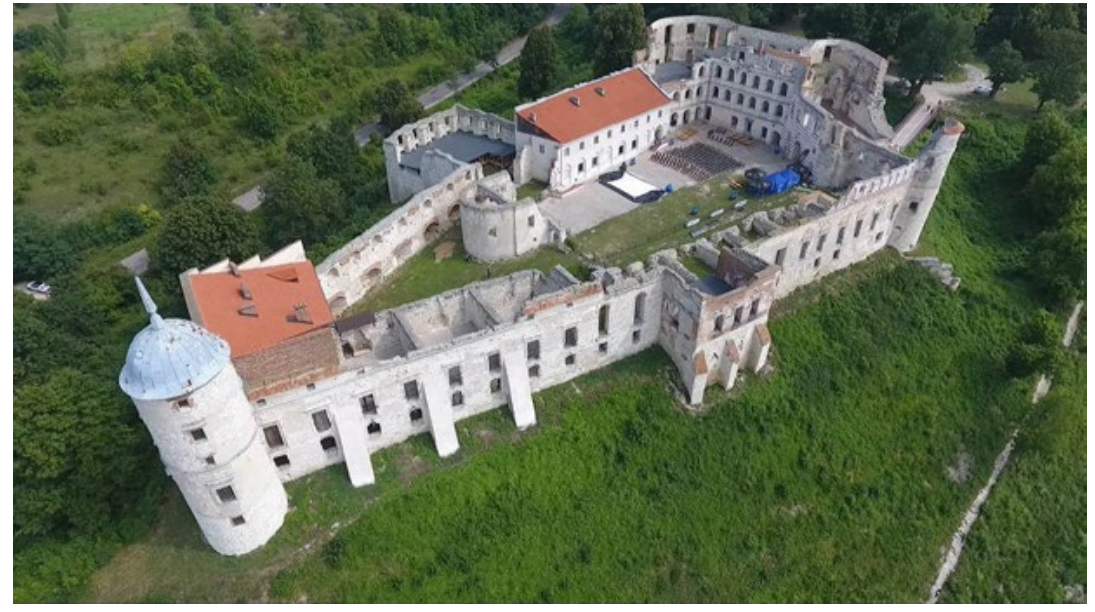

Ryc. 8. Widok z lotu ptaka na zamek i wzgórze zamkowe, 2018 rok Autor: Karol Krupa 


\section{Obecne funkcjonowanie}

Ruiny zamku w Janowcu, jak już wcześniej wspominano, funkcjonują obecnie jako jeden z oddziałów Muzeum Nadwiślańskiego w Kazimierzu Dolnym. Wraz z zespołem dworskim oraz parkiem zamkowym wchodzą w skład zespołu zamkowego. Zamek w większej części utrzymany w charakterze trwałej ruiny, częściowo udostępniony jest do ruchu turystycznego.

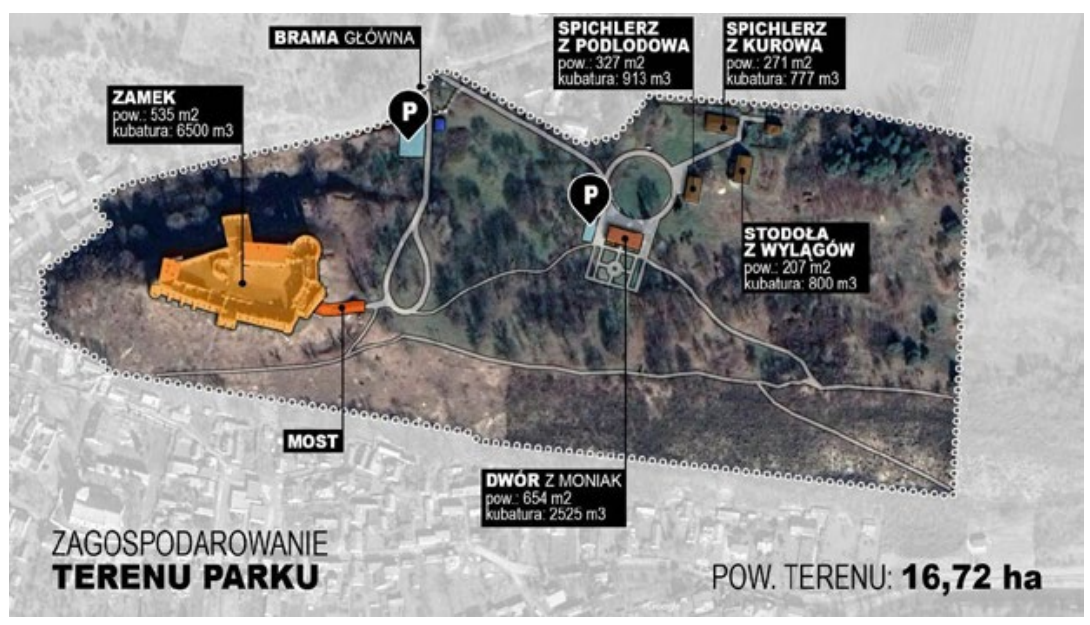

Ryc. 9. Zagospodarowanie terenu należącego do Muzeum Nadwiślańskiego w Kazimierzu Dolnym oddział Zamek w Janowcu. Źródło: opracowanie własne na podkładzie https://www.google. $\mathrm{pl} / \mathrm{maps}$

Obiekt znajduje się na terenie parku o powierzchni 16,72 ha. Rycina nr 9 przedstawia obecne zagospodarowanie wzgórza zamkowego oraz parku przy zamku. Od strony południowej znajduje się brama wjazdowa na teren. Tuż przy niej ulokowany jest niewielki parking dla turystów oraz stróżówka. W zachodniej części parku usytuowane są ruiny janowieckiego zamku, do których prowadzi stary tymczasowy most techniczny. Natomiast w północno-wschodniej części terenu znajduje się zespół dworski, w skład którego wchodzi dwór z Moniak, spichlerz z Podolowa, spichlerz z Kurowa oraz stodoła z Wylągów. Obiekty te zostały przeniesione do Janowca z pobliskich terenów Lubelszczyzny w latach 1978-1985. Obecnie organizowane są w nich wystawy czasowe, koncerty, spektakle teatralne, dodatkowo we dworze znajdują się pokoje gościnne.

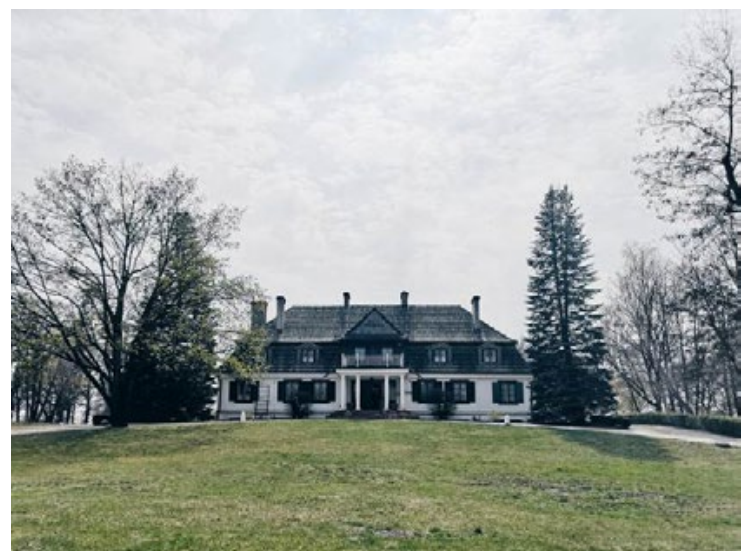

Ryc. 10. Dwór z Moniak. Autor: Katarzyna Drobek

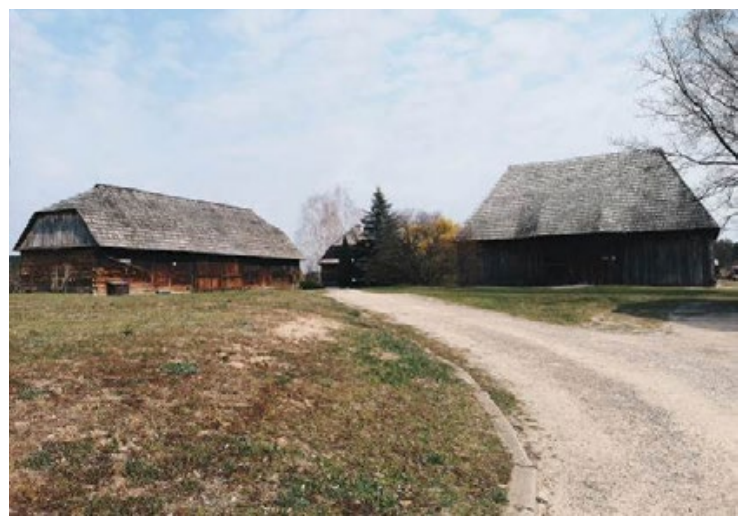

Ryc. 11. Spichlerz z Podolowa i spichlerz z Kurowa. Autor: Katarzyna Drobek 


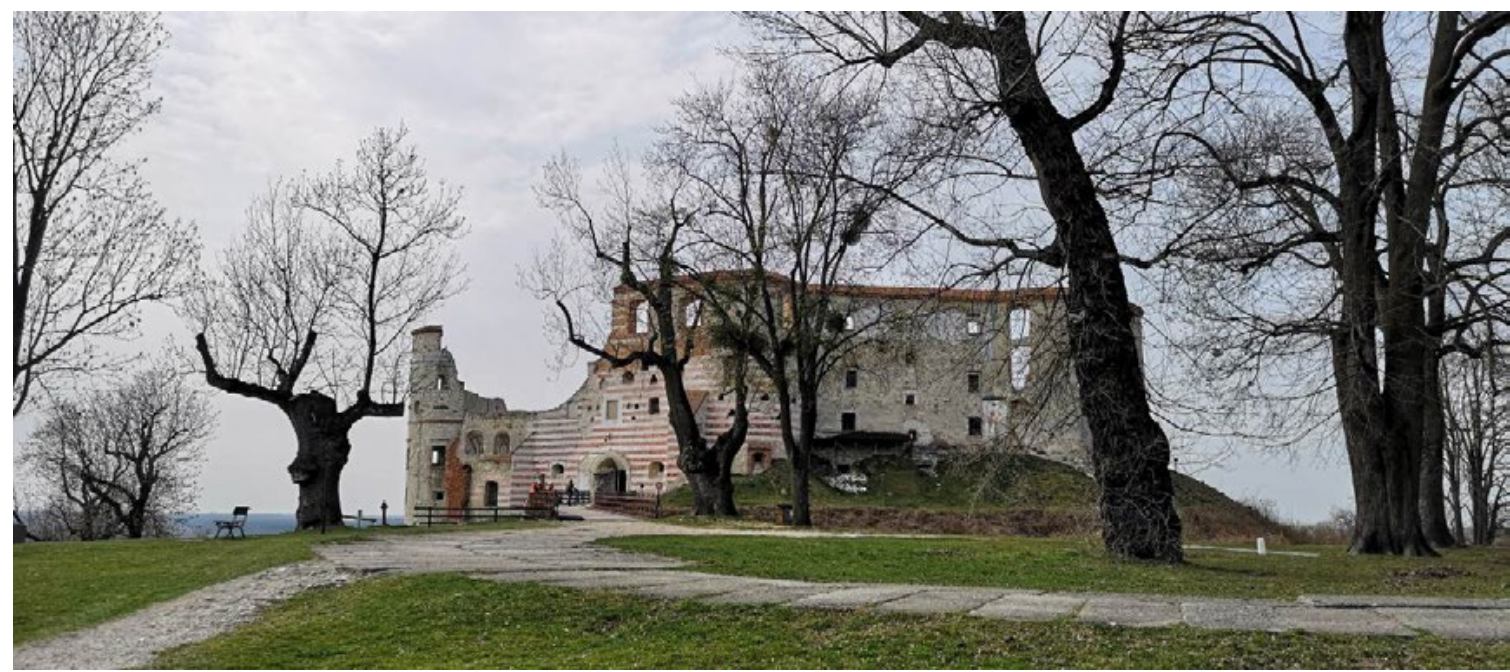

Ryc. 12. Widok z lotu ptaka na zamek i wzgórze zamkowe, 2018 rok. Autor: Katarzyna Drobek

W 1993 roku dla Zamku w Janowcu został wykonany Plan Realizacyjny Zagospodarowania Adaptacja Zamku dla potrzeb muzealno-turystycznych. Architekci Tomasz Augustynek oraz Bogdan Kulawczuk jako główne elementy funkcjonalne założyli powstanie ekspozycji historii zamku oraz ekspozycji sztuki obronnej, obsługę ruchu turystycznego, zespół imprezowy, imprezy plenerowe na dziedzińcu, zespół usług towarzyszących, pokoje gościnne, kawiarnia-bistro, bar kawowy-klub, szalet ogólnodostępny i zespół administracyjno-gospodarczo-techniczny. Plan ten przewidywał, że docelowo, po zakończeniu całego zadania na zamek w Janowcu będzie przybywać ok. 20000 turystów rocznie.

W ramach Planu Realizacyjnego wykonano głównie zabezpieczenia konstrukcyjne fundamentów i murów zamku, konserwację i restaurację detali architektonicznych połączonych z częściową rekonstrukcją budowli, m.in. krużganki w skrzydle wschodnim, Dom Północny oraz Apartament Zachodni. Na zamek wprowadzono funkcje muzealne oraz hotelowe, które obecne są do dnia dzisiejszego. Dom Północny stał się miejscem ekspozycji, natomiast $w$ jego kondygnacji podziemnej zlokalizowano zaplecze sanitarne zamku. W skrzydle wschodnim zlokalizowano cztery pokoje hotelowe. W kazamacie Bastei Wielkiej przez pewnie czas sezonowo funkcjonowała mała kawiarnia. Część budynku bramnego przeznaczono na kasy biletowe i sklep z pamiątkami oraz wystawy czasowe. Dziedziniec zamkowy stał się miejscem licznych imprez plenerowych.

\section{WYKRES ILOŚCI ZWIEDZAJACYCH W LATACH 1987-2004}

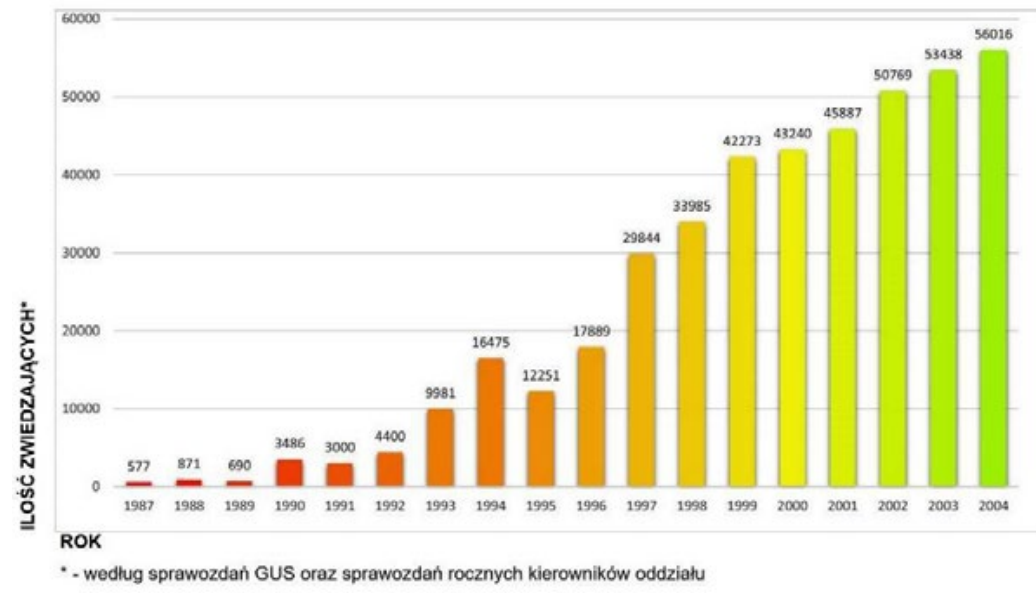

Ryc. 13. Wykres ilości zwiedzających w latach 1987-2004. Źródło: opracowanie własne na podstawie danych MNKD 
Pomimo iż plan nie został w pełni zrealizowany, bardzo szybko osiągnięto przewidywaną liczbę odwiedzających. W 1996 roku uruchomiona została przeprawa wodna przez Wisłę, prowadząca z Kazimierza do Janowca. Przyniosło to gwałtowny wzrost liczby turystów, znacznie ponad docelowe $20000^{5}$ (ryc. 13). W kolejnych latach odnotowano stały wzrost odwiedzających, który w 2004 roku wyniósł znacznie powyżej 50 000. W 2015 roku pojawił się przewodnik po zamku.

Obecnie zamek jest większej części niewykorzystany ze względu na jego zły stan techniczny. Wiele elementów warowni jest niedostępnych dla zwiedzających, ponieważ Amfilada południowa, wybudowa czeladna oraz Dziedziniec Mały mogą być oglądana jedynie zza barierki, Sala Rycerska znajdująca się nad przejazdem w Budynku Bramnym została wyłączona z ruchu turystycznego. Apartament Zachodni pozostawiono w stanie surowym.

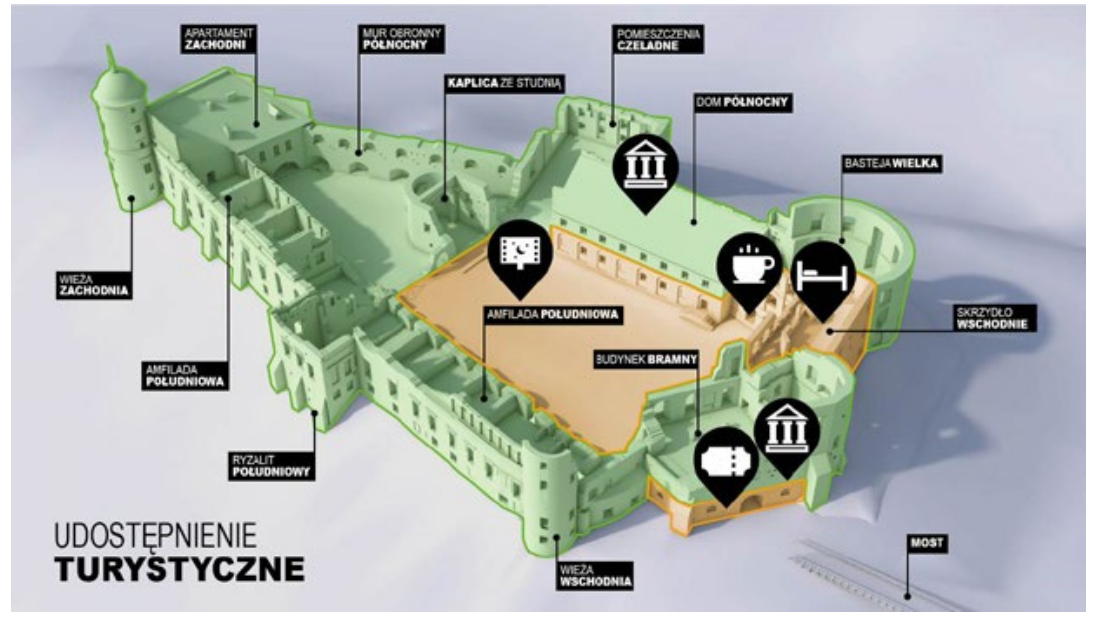

Ryc. 14. Udostępnienie turystyczne zamku w Janowcu. Źródło: opracowanie własne

Na rycinie nr 14 przedstawiony został stopień udostępnienia turystycznego zamku. Mimo tak niewielkiej części dostępnej dla zwiedzających oraz ciągłego wyłączania kolejnych części obiektu ze zwiedzania, ruiny cieszą się ogromnym zainteresowaniem. Obecna średnia frekwencja w oddziale wynosi około 70000 osób rocznie. (ryc. 15) W latach 2012-2014 odnotowano spadek zainteresowania obiektem w porównaniu do informacji z lat 1987-2004. Frekwencja wynosiła około 40000 odwiedzających, w 2015 wzrosła do 60000.

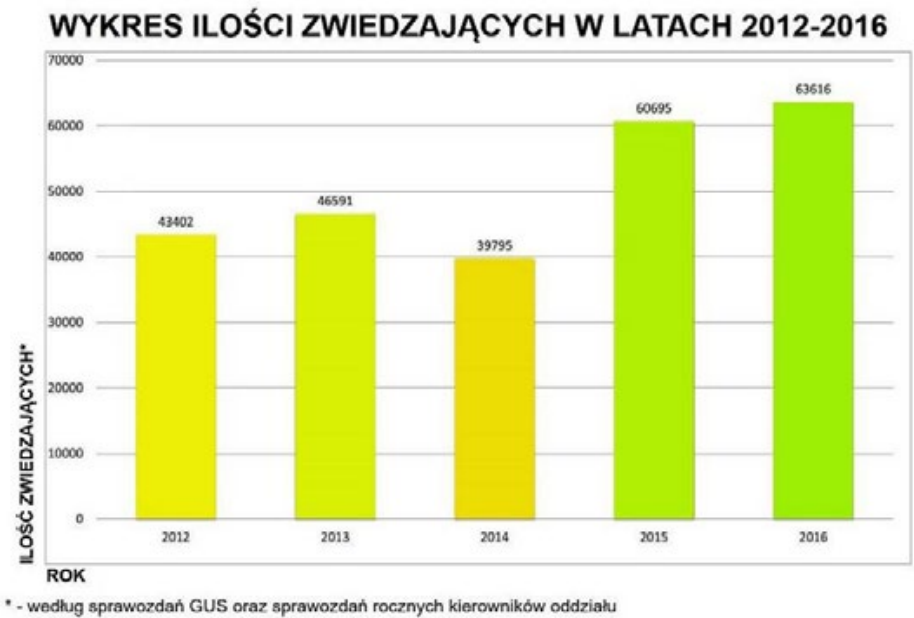

Ryc. 15. Wykres ilości zwiedzających w latach 2012-2016. Źródło: opracowanie własne na podstawie danych MNKD

Jak już wspomniano wcześniej, na terenie zamku organizowane są różnego rodzaju imprezy plenerowe. W ostatnich latach nastąpił ich wzrost ilościowy a same wydarzenia stały się bardziej różnorodne. Wiele imprez odbywa 
się tu cyklicznie. Najbardziej rozpoznawalnym oraz cieszącym się niesłabnącym zainteresowaniem jest Festiwal Filmu i Sztuki Dwa Brzegi, który od 2007 roku swoimi wydarzeniami łączy Kazimierz Dolny z Janowcem nad Wisłą ${ }^{6}$ Dawniej odbywał się jako Festiwal Filmu tylko i wyłącznie w Kazimierzu. Od 10 lat na zamku w Janowcu organizowane jest również Święto Wina. W jego trakcie promowane są lokalni producenci win, którzy działają w Stowarzyszeniu Małopolskiego Przełomu Wisły. Frekwencja wynosi około 2-3 tysięcy odwiedzających.

Dodatkowo co roku na zamku organizowana jest tematyczna majówka na zamku. Odbywają się tutaj także wydarzenia związane z obchodami Dni Janowca, Dnia Dziecka oraz Nocy Muzeów.

\section{Wiodące problemy}

W wyniku wojen oraz wieloletnich zaniedbań poprzednich właścicieli, zamek w Janowcu już od początku XIX w. powoli zamieniał się w ruinę. Od 1975 roku, kiedy to Muzeum Nadwiślańskie wykupiło obiekt, trwają prace badawcze, konserwatorskie i remontowe. Od tego czasu wykonano zabezpieczenia konstrukcyjne i wiele prac o charakterze remontowym i adaptacyjnym. Dzięki tym robotom zamek w większości został podźwignięty z gruzów. Niestety jednak nie wykonano wszystkich zaplanowanych wcześniej działań oraz część z nich okazała się być nieskuteczna.

W obecnym czasie zamek w Janowcu jest w złym stanie technicznym. Szereg obiektów uległo częściowej destrukcji, pojawiły się spękania, odspojenia materiału murowego oraz jego ubytki. Zauważalne jest również spore zawilgocenie muru. Na zamku występuje duża ilość wolno stojących ścian pozostawionych jest w formie trwałej ruiny, dlatego też są narażone na bezpośrednie, niszczące działanie czynników atmosferycznych. Do tego w miejscach zadaszonych kubatur pojawiają się nieszczelności pokrycia dachowego oraz obróbek blacharskich, nieprawidłowe spadki, źle wykonane izolacje przeciwwilgociowe powodują ogromne problemy. Dodatkowym problemem technicznym jest zieleń porastająca niektóre części koron murów.

W najgorszym stanie technicznym znajduje się mur północny oraz mur amfilady południowej. Mur północny to jedyny historycznie niezabudowany odcinek obwodu obronnego zamku z 1 ćw. XVI w. Pomimo zniszczenia korony w wyniku działania czynników atmosferycznych oraz rozebrania strzelnic działowych na materiał budowlany, konstrukcja muru była w dobrym stanie. W 1996 roku przeprowadzono jego konserwację, przemurowano fragmenty z opoki wapnistej pozostawiając ceglane opłaszczowanie. Obecnie, jak widać na ryc. 16, mur ten ulega stopniowej destrukcji i stanowi ogromne niebezpieczeństwo. ${ }^{7}$

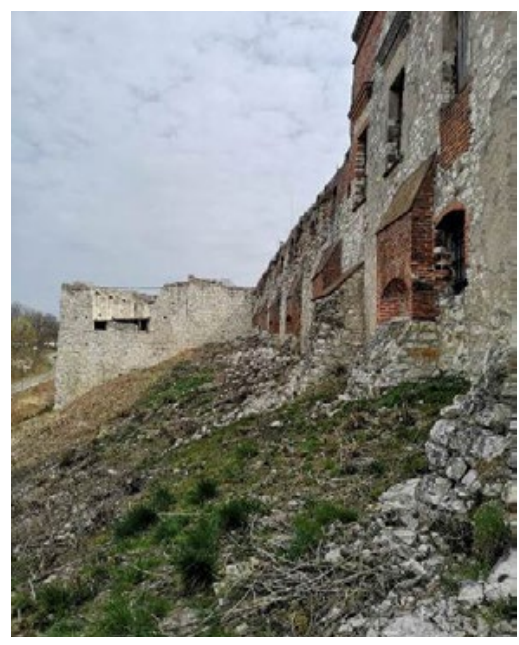

Ryc. 16. Zniszczenia muru północnego. Autor: Katarzyna Drobek

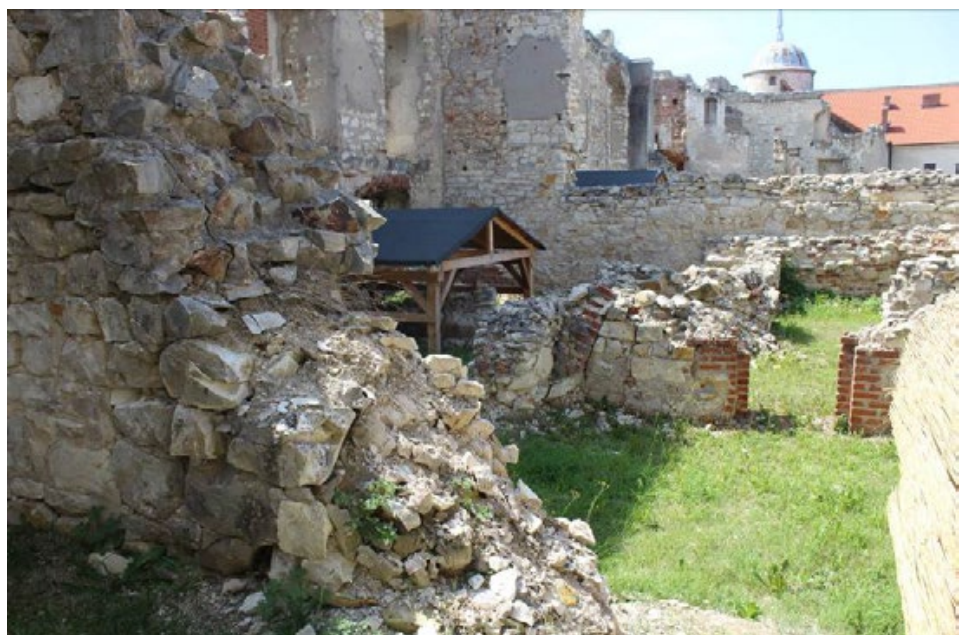

Ryc. 17. Mury dawnego pałacu przy amfiladzie południowej. Autor: Katarzyna Drobek

6 http://www.dwabrzegi.pl/ [dostęp 10.09.2019]

7 Klimek B., Zamek w Janowcu nad Wisłą - fazy budowy, przeprowadzone prace i ocena stanu technicznego poszczególnych części zamku, [w:] Ochrona i konserwacja ruin zamkowych - wybrane problemy i przykłady, Warszawa - Lublin, 2013, s. 89-101, 
W przypadku ścian dawnego pałacu wadliwie wykonane obróbki blacharskie gzymsów powodują zalewnie lica muru oraz wnikanie w niego wody. Skutkiem tego jest odpadanie z elewacji tynków wraz z wystrojem malarskim i zabytkową sztukaterią. W 2000 roku wymurowano ścianę północną oraz ściany wewnętrzne pałacu, w których po jednej zimie zaczęła złuszczać się warstwa zaprawy. Obecnie murki te są w bardzo złym stanie technicznym.

Wymienione powyżej problemy techniczne nie są wszystkimi problemami jakie występują na zamku w Janowcu. W niniejszym artykule przytoczono jedynie te najczęściej występujące. Jednakże na podstawie tych informacji jasno wynika z jakimi trudnościami spotykają się zarządcy obiektu i jakie są powody tak wielu wyłączonych części z ruchu turystycznego.

\section{Wnioski}

Malowniczo położony Zamek w Janowcu przyciąga do siebie wielu turystów. Pomimo sezonowości funkcji oraz niezbyt bogatego zagospodarowania turystycznego stanowi on ogromną atrakcję dla odwiedzających. Obecna roczna frekwencja wynosząca około 70000 turystów jest imponująca, biorąc pod uwagę tak niewielki w skali całego obiektu stopień udostępnienia oraz wielu braków funkcjonalnych obiektu.

Ruiny zamku w Janowcu posiadają ogromny potencjał na rozwój, jednakże podobnie jak w przypadku innych obiektów tego typu podstawową przeszkodą są finanse. Brak środków na podstawowe prace zabezpieczające blokuje możliwości powiększenia oferty turystycznej. Najbardziej oczekiwane zmiany w funkcjonowaniu takich obiektów jak zamek w Janowcu, powinny dotyczyć przede wszystkim do dążenia w celu zwiększenia ich dostępności i poprawy jakości ekspozycji muzealnej, ulepszenia promocji informacji i reklamy, poprawy zagospodarowania turystycznego, wzrost standardu świadczonych usług, poprawy infrastruktury (w tym parkingi) oraz większej liczby imprez i atrakcji.

\section{Bibliografia}

[1] Bogdanowski J., Trwała ruina zamku jako problem konserwatorsko-krajobrazowy, [w:] Ochrona Zabytków, 1977, nr 30/1-2 (116-117), s. 27-46.

[2] Bogdanowski J., Architektura obronna w krajobrazie Polski, PWN Wrocław - Kraków 1996.

[3] Zamki Lubelszczyzny w źródłach archeologicznych, pod red. E. Banasiewicz-Szykuły, Lublin 2015.

[4] Chlebowska D., Trwała ruina w Polsce koniecznym świadkiem historycznego krajobrazu, [w:] Wiadomości Konserwatorskie, nr 16/2004, s. 76-83.

[5] Frydryczak B., Historyczne formy waloryzacji ruin, [w:] Studia Europaea Gnesnensia 3, 2011, s. 175-194.

[6] Guerquin B., Zamki w Polsce, Warszawa 1984.

[7] Gruszecki A., Zamek w Janowcu w świetle badań, [w:] Ruiny żywe: adaptacja zabytków architektury do celów muzealnych: nowe inspiracje i funkcje dla Zamku w Janowcu: materiały z sympozjum naukowego z okazji 30-lecia Muzeum Zamek w Janowcu, Kazimierz Dolny - Janowiec 2007, s. 13-16.

[8] Kajzer L., Kołodziejski S., Salm J., Leksykon zamków w Polsce, Warszawa 2012.

[9] Longa J., Zaniewski P., Od funkcji obronnej do muzealnej. Średniowieczny zamek w Niepołomicach jako przykład przekształceń funkcjonalnych w historycznej strukturze, [w:] Zeszyty Naukowe Politechniki Śląskiej, Architektura z. 51, 2012, s. 37-51.

[10] Klimek B., Zamek w Janowcu nad Wisłą - fazy budowy, przeprowadzone prace i ocena stanu technicznego poszczególnych części zamku, [w:] Ochrona i konserwacja ruin zamkowych - wybrane problemy i przykłady, Warszawa - Lublin 2013, s. 89-101.

[11] Kocańda P., Ruiny zamków jako przykład obiektów muzealnych na "wolnym powietrzu". Wstęp do problematyki i historia zainteresowań do 1914 roku, [w:] Młoda Muzeologia t. I, 2016, s. 34-46.

[12] Malawska I., Zamki w Polsce - problem określenia zasobu, Ochrona Zabytków 4/2007, Warszawa 2007, s. 83-86.

[13] Molski P., Czynniki kulturowe i czynniki pozakonserwatorskie a postępowanie z zamkami w ruinie. Wnioski, [w:] Ochrona i konserwacja ruin zamkowych - wybrane problemy i przykłady, Warszawa - Lublin 2013, s. 41-47.

[14] Przyłęcki M., Trwałe ruiny historycznych obiektów w krajobrazie miast, Architektura Krajobrazu, 2007, nr 3, s. 25-34. 
[15] Teodorowicz-Czerepińska J., Zamki Kazimierza Wielkiego na Lubelszczyźnie, Kalendarz Lubelski, 1972.

[16] Supryn M., Badania archeologiczne zamku w Janowcu, [w:] Ruiny żywe: adaptacja zabytków architektury do celów muzealnych: nowe inspiracje i funkcje dla Zamku w Janowcu: materiały z sympozjum naukowego z okazji 30-lecia Muzeum Zamek w Janowcu, Kazimierz Dolny - Janowiec 2007, s. 25-48.

[17] Szmygin B., Problem ruin w świetle współczesnej teorii i praktyki konserwatorskiej, [w:] Ruiny żywe: adaptacja zabytków architektury do celów muzealnych: nowe inspiracje i funkcje dla Zamku w Janowcu: materiały z sympozjum naukowego z okazji 30-lecia Muzeum Zamek w Janowcu, Kazimierz Dolny - Janowiec 2007, s. 89-98.

[18] Szmygin B., Trwała ruina : granice i uwarunkowania działań konserwatorskich na przykładzie zamku w Janowcu nad Wisłą, [w:] Ochrona Zabytków 50/1, 1997, s. 12-18.

[19] Żurawski J., Okoliczności i cel nabycia zamku w Janowcu nad Wisłą. Przebieg jego konserwacji, restauracji i zagospodarowania, [w:] Ruiny żywe: adaptacja zabytków architektury do celów muzealnych: nowe inspiracje i funkcje dla Zamku w Janowcu: materiały z sympozjum naukowego z okazji 30-lecia Muzeum Zamek w Janowcu, Kazimierz Dolny - Janowiec 2007 s. 17-24.

[20] Żurawski J., Zamek w Janowcu nad Wisłą. Budowa - Rozbudowa - Ruina - Konserwacja - Rewaloryzacja - Zagospodarowanie, [w:] Ochrona Zabytków, Nr 1-2/2003, Narodowy Instytut Dziedzictwa, s. 5-33.

\section{Strony internetowe}

[21] http://www.dwabrzegi.pl/ [dostęp 10.09.2019]

[22] https://medievalheritage.eu/ [dostęp 28.09.2019]

[23] https://zabytek.pl/ [dostęp 10.09.2019]

[24] https://www.mnkd.pl/ [dostęp 10.09.2019] 